\title{
SOME CULTURAL REACTIONS OF CLOSTRIDIUM TETANI
}

\author{
A. T. Willis and Kathleen Williams \\ Public Health Laboratory, Lewsey Road, Luton
}

\section{Plates XXV-XXIX}

THERE are conflicting views concerning the proteolytic and gelatinase activities of Clostridium tetani.

Some contemporary workers consider that the organism is non-proteolytic (Reed and Orr, 1941; Willis, 1964). Smith (1955), and Smith and Holdeman (1968), on the other hand, stated that " Coagulated serum or egg is softened and digested ", and Breed, Murray and Smith (1957) recorded in Bergey's Manual that coagulated albumin is slowly liquefied. Wilson and Miles (1964) and Cruickshank (1965) also regarded the organism as proteolytic. The absence of any demonstrable proteolytic effect on milk medium was noted by Adamson (1919-20), Hall (1922), Reddish and Rettger (1924), Fildes (1925), Spray (1936) and Reed and Orr, and, though old cultures of $\mathrm{Cl}$. tetani in cooked meat broth may show slight blackening, there is no clear evidence that this is due to digestion (Adamson and Cutler, 1917; Robertson, 1917; Adamson; Hall; Reddish and Rettger).

Reports in the literature suggest that any gelatinase activity of $\mathrm{Cl}$. tetani is slow, late and variable (Adamson; Hall; Kendall, Day and Walker, 1922; Reddish and Rettger; Fildes; Walbum and Reymann, 1934; and Spray). Although Adamson stated that gelatin was completely liquefied in 3-4 days, Kendall et al. reported that it was not softened after 3 weeks' incubation. Hall reported that whilst some strains of $\mathrm{Cl}$. tetani liquefied gelatin, others merely lowered its solidification point. Similarly, Fildes noted that "Although the tetanus bacillus leads to a liquefaction of gelatin . . . nevertheless this does not take place with equal facility with all strains. Whereas some will cause liquefaction in 3 or 4 days at $37^{\circ} \mathrm{C}$, others will require 3 or 4 weeks or must be tested more than once ".

In the present study of 71 strains of $\mathrm{Cl}$. tetani, we have re-examined the proteolytic and gelatinase activities of the organism using a variety of complex protein and gelatin media. In the course of these investigations, a new and almost species-specific reaction of $\mathrm{Cl}$. tetani in cultures on milk agar was noted, and incidental observations were made on the inhibitory effect of horse tetanus antitoxic sera on the swarming growth of the organism in surface culture. The 71 strains were also examined for deoxyribonuclease and phosphatase activity.

\section{MATERIALS AND METHODS \\ Organisms}

A total of 71 strains of $\mathrm{Cl}$. tetani was examined, together with strains of $\mathrm{Cl}$. histolyticum (NCTC7123), Cl. sporogenes (NCTC 275, 276, 532, 533), Cl. welchii type A (NCTC 8799, 9851, 10239, 10240), Cl. septicum (NCTC 281, 284, 547), Cl. chauvoei (NCTC8596), Cl. oedematiens type A (NCTC538), Cl. oedematiens type B (NCTC9691), Cl. bifermentans (NCTC8780), Cl. botulinum type A (NCTC7272), Cl. botulinum type B (NCTC7273),

Received 4 Sept. 1969; accepted 2 Oct. 1969.

J. MED. MICROBIOL.-VOL. 3 (1970) 
Cl. botulinum type C (NCTC 3732, 8264) and Cl. tetanomorphum (NCTC543). Organisms other than $\mathrm{Cl}$. tetani were used for control and comparison purposes.

Of the 71 strains of $\mathrm{Cl}$. tetani, 26 were isolates from soil samples collected in different parts of England and Wales, and 30 were strains isolated from new disposable bed-pans; these were kindly provided by Drs W. J. Ryan and J. H. Payne. The remaining 15 strains, kindly provided by Dr S. P. Lapage, were National Collection strains as follows: NCTC 2933, 2934, 2935, 2936, 2937, 2938, 5405, 5409, 9568, 9569, 9570, 9571, 9573, 9574 and 9575. Twenty-three of these 71 strains were non-toxigenic.

\section{Culture media and reagents}

The nutrient base used in all the following media was heart infusion broth prepared from fat-free ox hearts. Unless otherwise stated, agar media contained 3.0 per cent. of Davis New Zealand agar. Sterilisation was at $121^{\circ} \mathrm{C}$ for $15 \mathrm{~min}$. For satisfactory surface growth of exacting species such as $\mathrm{Cl}$. oedematiens type B, cysteine hydrochloride $(0.05$ per cent.) was added to the medium (Moore, 1968).

Robertson's cooked meat medium, Loeffler's inspissated serum, fresh horse blood agar and heated blood agar were prepared as described by Collins (1967).

Glucose gelatin and gelatin agar (Frazier, 1926) were as described by Willis and Hobbs (1959).

Heated serum agar was as described by Willis and Hobbs, except that sucrose and neutral red were omitted from the medium, and horse serum was used in place of human serum.

Heated egg albumin agar was prepared in the same way as heated serum agar, egg albumin being substituted for horse serum.

Milk agar was as described by Reed and Orr.

Fibrin agar was prepared from human thrombin and fibrinogen (Lister Institute) as described by Jacobs, Willis and Goodburn (1964); fibrin agar with trypsin inhibitor was prepared in the same way, except that soy bean trypsin inhibitor (Worthington Biochemical Corporation) was added (Lack and Wailling, 1954).

Gelatin disks used were Charcoal Gelatin Discs (Oxoid).

Phenolphthalein phosphate agar was as described by Bray and King (1943).

Deoxyribonucleic acid (DNA) agar was as described by Jacobs $e t$ al.

\section{Inoculation of media}

The agar media were spot- or streak-inoculated in the usual way with a charged loop. For spot inocula, a 9-cm petri dish conveniently accommodated five cultures. The tubed media were inoculated with a pasteur pipette after dissolved oxygen had been driven off by steaming and cooling. Care was taken to inoculate the glucose gelatin while it was still fluid. All inoculated media were incubated at $37^{\circ} \mathrm{C}$ in the anaerobic jar. In all cases inocula came from fresh 18-24-hr cooked-meat broth cultures of the clostridia listed above, and, where appropriate, positive and negative controls were included with each batch of organisms examined. In some cases, " half-antitoxin " plates were employed, treated with commercial horse tetanus antitoxic serum* (Wellcome).

\section{Reading of results}

Glucose gelatin. Duplicate cultures were read after 2 and 4 days' incubation. Liquefaction was recorded if the medium remained fluid after half an hour in the cold room at $4^{\circ} \mathrm{C}$.

Gelatin agar. Cultures were tested for gelatinase activity after 48 hours' incubation by flooding the plates with acid mercuric chloride solution (15 per cent. mercuric chloride in 20 per cent. hydrochloric acid). Gelatinase-producing cultures were surrounded by a zone of clearing in the medium.

* This rather clumsy phrase has to be used as it is extremely improbable that the effects of the serum recorded in this paper are due to tetanus antitoxin. 
Charcoal gelatin disks. A charcoal gelatin disk was incubated in a cooked-meat broth culture of the organism under test, and was examined after 2 and 4 days' incubation. Gelatinase activity was indicated by release of charcoal particles into the medium.

Cooked-meat broth. Cultures were read at weekly intervals for $4 \mathrm{wk}$. Proteolysis was indicated by breakdown and discoloration of the meat particles.

Loeffler's inspissated serum. Heavily inoculated cultures in quadruplicate were read after 1, 2, 3 and 4 weeks' incubation. Proteolysis was indicated by the development of surface erosion or by disintegration or liquefaction of the medium.

Milk agar, heated serum agar, heated egg albumin agar and heated blood agar. Duplicate cultures were read after 2 and 4 days' incubation. Proteolysis was indicated by the development of zones of clearing or partial clearing about areas of growth.

Fibrin agar and fibrin agar with trypsin inhibitor. Duplicate cultures on each medium were read after 2 and 4 days' incubation. Proteolysis was indicated by the development of

TABLE I

Gelatinase activity of 71 strains of $\mathrm{Cl}$. tetani determined by three different methods

\begin{tabular}{c|c|c|c}
\hline \multirow{2}{*}{$\begin{array}{c}\text { Incubation period } \\
(\mathrm{hr})\end{array}$} & \multicolumn{3}{|c}{$\begin{array}{c}\text { Number (and percentage) of strains giving a positive } \\
\text { result with }\end{array}$} \\
\cline { 2 - 4 } & glucose gelatin & gelatin agar & charcoal gelatin disks \\
\hline 48 & $16(22.5)$ & $71(100)$ & $17(23.9)$ \\
96 & $28(39 \cdot 4)$ & $\ldots$ & $70(98 \cdot 5)$ \\
\hline
\end{tabular}

$\ldots=$ Not tested.

zones of clearing about areas of growth on both media; kinase activity was indicated by clearing on the plain fibrin agar plate only.

Phenolphthalein phosphate agar. Duplicate cultures on this medium were exposed to ammonia vapour and read for phosphatase activity after 2 and 4 days' incubation.

DNA agar. Cultures on plates were flooded with $1 \cdot 5 \mathrm{~N}-\mathrm{HCl}$ after 48 hours' incubation; positive colonies showed an area of clearing around them.

\section{RESULTS \\ Gelatinase and proteinase activity}

The findings for the gelatinase and proteinase activity of the 71 strains of Cl. tetani examined are summarised in tables I and II.

Only 16 of the strains of $\mathrm{Cl}$. tetani showed gelatinase activity in the conventional nutrient glucose gelatin medium after 48 hours' incubation, and only 17 showed activity in the charcoal gelatin disk test, at a time when all 71 strains gave clear positive reactions in the gelatin agar test of Frazier. After 4 days' incubation, when the experiment was stopped, only 28 strains were gelatinolytic as judged by the glucose gelatin test, but 70 were positive in the charcoal disk test. The single negative strain in the disk test was also negative in the conventional glucose gelatin. Although it seems likely that the number of positive strains in nutrient glucose gelatin would have increased with more extended incubation, 4 days seemed an adequate period if the test was to be regarded as 
useful. In any event, the high sensitivity of the Frazier test (100 per cent. of strains positive after $48 \mathrm{hr}$ ), and of the charcoal gelatin disk test ( 99 per cent. positive after $96 \mathrm{hr}$ ), indicates that the nutrient glucose gelatin method should be abandoned.

Cultures of the 71 strains of $\mathrm{Cl}$. tetani on the seven different complex protein media were uniformly non-proteolytic. A proportion of the strains produced sharp zones of clearing on fibrin agar, but because this activity was abolished by soy bean trypsin inhibitor, this fibrinolysis was considered to be due to a kinase and not to a true proteinase.

TABLE II

Proteolytic activity of 71 strains of $\mathrm{Cl}$. tetani on seven different media

\begin{tabular}{|c|c|c|c|c|c|c|c|c|}
\hline \multirow[b]{2}{*}{$\begin{array}{l}\text { Incubation } \\
\text { period } \\
\text { (days) }\end{array}$} & \multicolumn{8}{|c|}{ Number of strains producing a positive result with } \\
\hline & $\begin{array}{c}\text { cooked- } \\
\text { meat } \\
\text { broth }\end{array}$ & $\begin{array}{l}\text { inspis- } \\
\text { sated } \\
\text { serum }\end{array}$ & $\begin{array}{c}\text { heated } \\
\text { serum } \\
\text { agar }\end{array}$ & $\begin{array}{l}\text { heated } \\
\text { egg } \\
\text { albumin } \\
\text { agar }\end{array}$ & $\begin{array}{c}\text { heated } \\
\text { blood } \\
\text { agar }\end{array}$ & $\begin{array}{l}\text { milk } \\
\text { agar }\end{array}$ & $\begin{array}{c}\text { fibrin } \\
\text { agar }\end{array}$ & $\begin{array}{c}\text { fibrin } \\
\text { agar plus } \\
\text { trypsin } \\
\text { inhibitor }\end{array}$ \\
\hline $\begin{array}{r}2 \\
4 \\
7 \\
14 \\
21 \\
28\end{array}$ & $\begin{array}{l}0 \\
0 \\
0 \\
0 \\
0 \\
0\end{array}$ & $\begin{array}{l}0 \\
0 \\
0 \\
0 \\
0 \\
0\end{array}$ & $\begin{array}{l}0 \\
0 \\
\ldots \\
\ldots \\
\ldots \\
\ldots\end{array}$ & $\begin{array}{l}0 \\
0 \\
\ldots \\
\ldots \\
\ldots \\
\ldots\end{array}$ & $\begin{array}{l}0 \\
0 \\
\cdots \\
\cdots \\
\cdots \\
\ldots\end{array}$ & $\begin{array}{l}0^{*} \\
0^{*} \\
\cdots \\
\cdots \\
\cdots \\
\cdots\end{array}$ & $\begin{array}{l}25 \\
49 \\
\ldots \\
\ldots \\
\cdots \\
\cdots\end{array}$ & $\begin{array}{l}0 \\
0 \\
\cdots \\
\cdots \\
\cdots \\
\cdots\end{array}$ \\
\hline
\end{tabular}

$\begin{aligned} \cdots & =\text { Not tested. } \\ * & =\text { Intense diffuse opacity produced by all strains. }\end{aligned}$

\section{A rennin-like activity of $C l$. tetani}

In the course of investigating the proteolytic activity of $\mathrm{Cl}$. tetani in cultures on milk agar, it was noted that all strains produced an intense diffuse opacity in the medium similar in appearance to that caused by lecithinase C-producing organisms on egg yolk agar. This reaction was evident only in cultures on firm ( 3 per cent. agar) milk plates, in which restriction of bacterial growth, and consequently of the opacity, permitted the detection of this change in the medium. From previous experience it was known that lactose-fermenting organisms, such as $\mathrm{Cl}$. welchii, may produce this sort of appearance on milk agar by acid precipitation of the caseinogen (Willis, unpublished). It seemed unlikely, however, that this was the mechanism of opacity production by $\mathrm{Cl}$. tetani, because this organism is in our hands entirely non-saccharolytic. The only other explanation that might account for the effect is the production by Cl. tetani of a rennin-like enzyme which would cause enzymatic clotting or precipitation of the milk as opposed to acid curdling (see Hall).

Effect of rennin and $\mathrm{Cl}$. tetani culture supernates on milk agar. A 30 per cent. solution of rennin (Griffin and George) in sterile distilled water was spotted on duplicate plates of firm milk agar, and wells were punched in the medium with a cork borer and filled with the enzyme solution. Similar plates were prepared 
using phenolised tetanus culture-supernatants instead of rennin solution. All plates were incubated aerobically and anaerobically at $37^{\circ} \mathrm{C}$. After $24 \mathrm{hr}$ the enzyme- and culture-supernatant-treated areas of both the aerobic and anaerobic plates showed zones of diffuse opacity identical in appearance to that produced by the growing culture of $\mathrm{Cl}$. tetani on anaerobic milk agar (figs. 1 and 3).

Rennin-like activity in milk broth. Some strains of $\mathrm{Cl}$. tetani cause simple clotting or precipitation in cultures in whole milk, a reaction that is doubtless due to their rennin-like activity. However, this reaction is inconstant from strain to strain, and varies even with the same strain when tested on different occasions. Moreover, the reaction, when it does occur, is always late to develop, and may require as long as 2-3 weeks' incubation (Hall; Reddish and Rettger; Spray; Reed, 1948). Among our own 71 strains tested in whole-milk medium, none produced any detectable change after 48 hours' incubation. After 7 days' incubation, three cultures showed simple coagulation of the milk, and after 14 days 52 cultures showed either a simple clot or partial precipitation of the casein; the remaining 19 cultures were negative.

In view of the constancy of the reaction of $\mathrm{Cl}$. tetani and its speed of development in 10 per cent. milk agar, experiments were conducted with a nutrient broth medium containing concentrations of skimmed milk varying from 5 to 20 per cent. Fresh young cultures of $\mathrm{Cl}$. tetani were inoculated into these media and incubated anaerobically for $18 \mathrm{hr}$ at $37^{\circ} \mathrm{C}$. Uninoculated control tubes were included, together with tubes of the medium inoculated with $\mathrm{Cl}$. sporogenes (proteolytic), and with a few drops of 10 per cent. rennin solution.

All 71 strains of $\mathrm{Cl}$. tetani, and tubes inoculated with rennin showed an identical result, which was best developed in 10 per cent. milk broth. There was complete precipitation of the milk, with a coarse white floccular deposit in a virtually clear supernatant fluid. The opalescent, semi-opaque appearance of the uninoculated medium was unaltered, whilst tubes containing $\mathrm{Cl}$. sporogenes showed almost complete clearing of the medium with a little fine white bottom deposit consisting mainly of bacterial cells (fig. 2).

A variety of clostridia was then tested on milk agar, and in 10 per cent. milk broth for comparison with the reactions of $\mathrm{Cl}$. tetani. These results are summarised in table III.

As might be expected, proteolytic species ( $\mathrm{Cl}$. sporogenes, $\mathrm{Cl}$. bifermentans, Cl. histolyticum and $\mathrm{Cl}$. botulinum types $\mathrm{A}$ and $\mathrm{B}$ ) produced an early precipitate or opacity in the medium, followed by rapid digestion and clearing. Lactosefermenting organisms, notably $\mathrm{Cl}$. welchii and $\mathrm{Cl}$. septicum, produced an early precipitate or opacity due to acid formation; in the fluid medium this was distinguished from the rennin reaction of $\mathrm{Cl}$. tetani by the addition of a little phenol red indicator at the end of the incubation period. Because the strains of $\mathrm{Cl}$. oedematiens types $\mathrm{A}$ and $\mathrm{B}$ produced reactions identical with those of Cl.tetani, it is concluded that these organisms also produce a rennin-like enzyme. As might be expected, the precipitate of caseinogen produced by lactosefermenting organisms redissolved when the cultures were neutralised, in contrast with that due to rennin and to cultures of $\mathrm{Cl}$. tetani, the development of which was favoured by an alkaline reaction and was optimal at $p \mathrm{H} 9$. 
Inhibition of the rennin-like activity of $\mathrm{Cl}$. tetani by $\mathrm{Cl}$. tetani antitoxic sera. The qualitative effect of tetanus antitoxic sera on the rennin-like activity of Cl. tetani was examined in two ways. (1) "Half-antitoxin" plate cultures were prepared on firm milk agar, two strains of $\mathrm{Cl}$. tetani being accommodated on each plate. Duplicate plates were prepared in each case, commercial horse tetanus antitoxic serum (Wellcome) being used for one plate and horse $\mathrm{Cl}$. welchii typing control serum (Wellcome) for the other. Plates were incubated anaerobically at $37^{\circ} \mathrm{C}$ for $24 \mathrm{hr}$. (2) Phenolised culture-supernatants prepared from 24-hr cultures of $\mathrm{Cl}$. tetani in cooked-meat broth were pipetted into wells punched into plates of milk agar. Horse tetanus antitoxic serum and

TABLE III

Reactions of some clostridia in milk broth and milk agar during 48 hours' incubation

\begin{tabular}{|c|c|c|c|c|}
\hline \multirow{3}{*}{$\begin{array}{c}\text { Organism } \\
\text { (and number of strains) }\end{array}$} & \multicolumn{4}{|c|}{ Reaction during 48 hours' incubation in } \\
\hline & \multicolumn{2}{|c|}{ milk agar } & \multicolumn{2}{|c|}{ milk broth } \\
\hline & Opacit & learing & Precipitate- & igestion \\
\hline $\begin{array}{l}\text { Cl. welchii type A (4) } \\
\text { Cl. chauvoei (1) } \\
\text { Cl. septicum (3) } \\
\text { Cl. botulinum type A (1) } \\
\text { Cl. botulinum type B (1) } \\
\text { Cl. botulinum type C (2) } \\
\text { Cl. oedematiens type A (1) } \\
\text { Cl. oedematiens type B (1) } \\
\text { Cl. bifermentans (1) } \\
\text { Cl. } \\
\text { Cl. horogenes }(4) \\
\text { Cl. tetanticumorphum (1) } \\
\text { Cl. tetani (71). }\end{array}$ & $\begin{array}{l}+ \\
\pm \\
+ \\
+ \\
+ \\
+ \\
+ \\
+ \\
+ \\
+ \\
+ \\
+\end{array}$ & $\begin{array}{l}= \\
= \\
- \\
+ \\
\pm \\
= \\
= \\
+ \\
+ \\
+ \\
+ \\
-\end{array}$ & $\begin{array}{l}+ \\
\pm \\
+ \\
+ \\
+ \\
\pm \\
+ \\
+ \\
+ \\
+ \\
+ \\
+ \\
+\end{array}$ & $\begin{array}{l}\overline{-} \\
\overline{+} \\
\pm \\
\pm \\
= \\
\overrightarrow{+} \\
+ \\
\pm \\
\pm \\
-\end{array}$ \\
\hline
\end{tabular}

Cl. welchii typing control serum were allowed to diffuse against the supernatants from adjacent wells, duplicate plates being incubated at $37^{\circ} \mathrm{C}$ under aerobic and anaerobic conditions.

In all the half-antitoxin milk agar plate cultures, the opalescence reaction of Cl. tetani was inhibited by tetanus antitoxic serum, but not by the $\mathrm{Cl}$. welchii control serum. In both the aerobic and anaerobic punch-hole diffusion plates, the culture-supernatants of $\mathrm{Cl}$. tetani produced an intense opalescence that was inhibited only by the tetanus antitoxic serum (figs. 3 and 4).

\section{Effect of tetanus antitoxin on the growth of Cl. tetani in plate cultures}

In the course of studying the inhibitory effect of $\mathrm{Cl}$. tetani antitoxic serum on the rennin-like activity of $\mathrm{Cl}$. tetani, the non-motile variant, Tulloch type VI (NCTC 9569), was cultured on half-antitoxin milk agar plates that contained only 1.5 per cent. of agar. It was thought that the lower concentration of agar 
Cultural reactions of CL.tetani

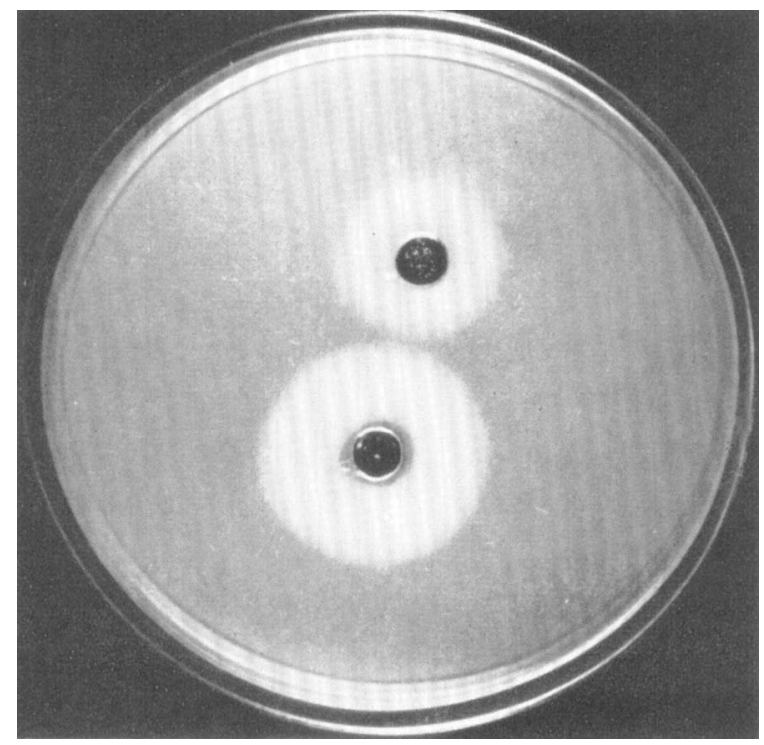

FiG. 1.--Acrobic milk agar punch plate, treated with $\mathrm{Cl}$. tetani culture-supernatant (top hole) and rennin solution (bottom hole). $\times \frac{3}{4}$.

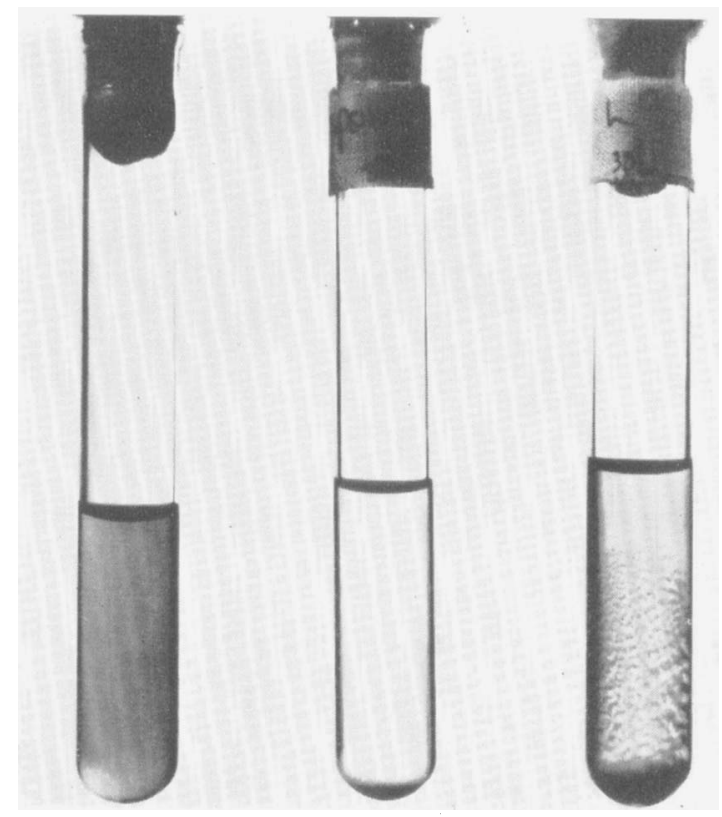

FIG. 2.-Cultures of Cl. sporogenes (centre) and Cl. tetani (right) in 10 per cent. milk broth. Uninoculated control (left). $\times \frac{3}{4}$. 
CUltural Reactions of CL. TETANI

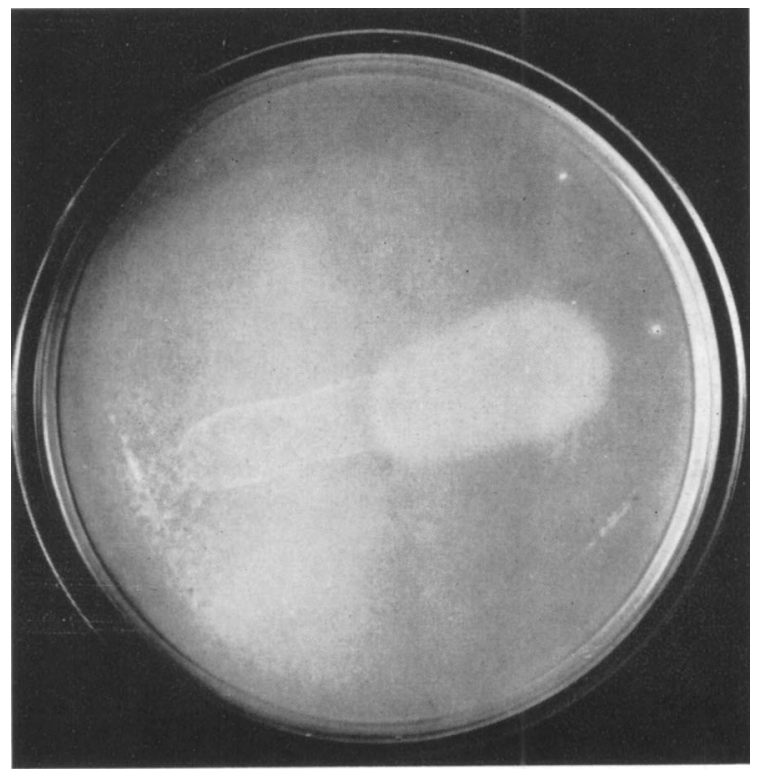

FIG. 3.-Culture of $\mathrm{Cl}$. tetani on firm milk agar. Tetanus antitoxin serum on the left-hand half of the plate inhibits the diffuse rennin opacity. $\times \frac{3}{4}$.

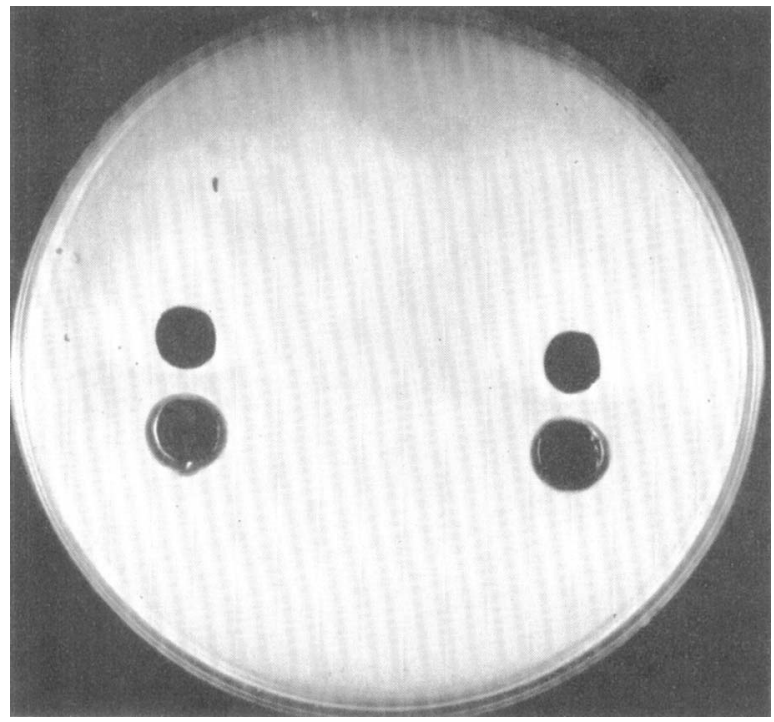

Fig. 4.-Aerobic milk agar punch plate, treated with $\mathrm{Cl}$. tetani culture-supernatants (top holes) and tetanus antitoxic serum (bottom holes). $\times \frac{3}{4}$. 


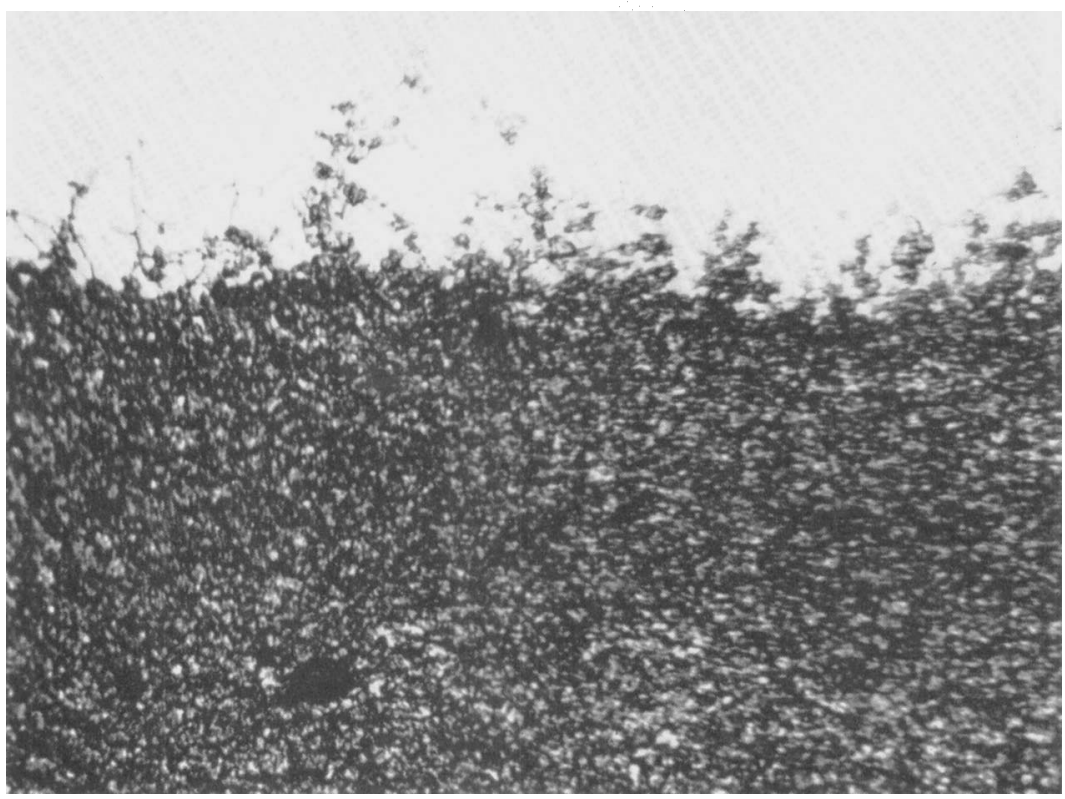

FIG. 5.-Edge of confluent growth of Cl. tetani type VI (non-motile) on the antitoxic serum-free half of a half-antitoxic serum (tetanus) fresh blood agar plate. Note the short fine rhizoidal outgrowths. $\times 18$.

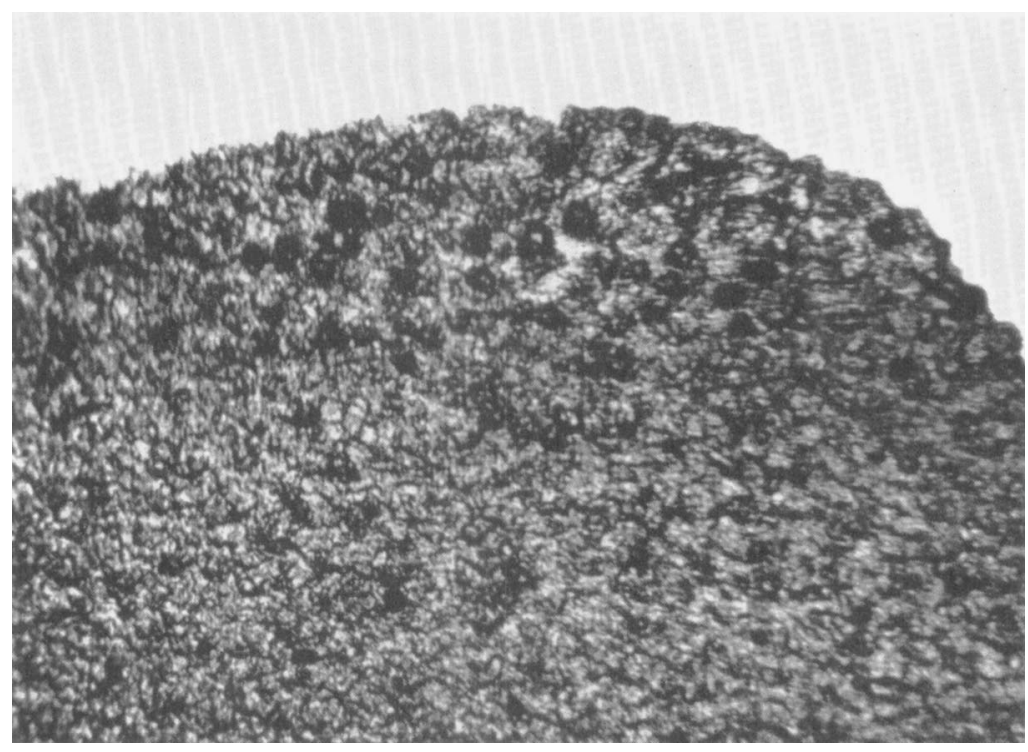

FIG. 6.-Edge of confluent growth of Cl. tetani type VI (non-motile) on the antitoxic serum-treated half of a half-antitoxic serum (tetanus) fresh blood agar plate. Rhizoidal outgrowths are absent, $\times 22 \cdot 5$, 
Cultural REACTIONS OF CL. TETANI

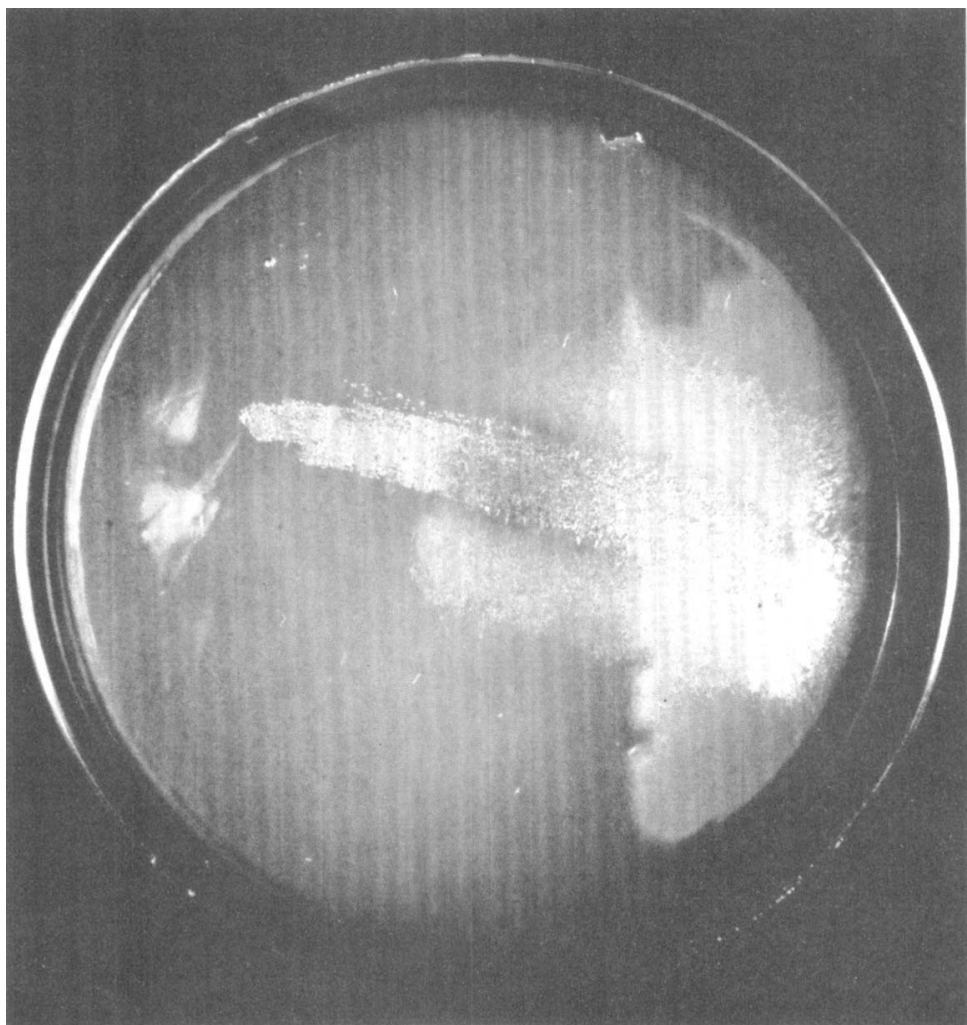

FIG. 7.--Motile strain of $\mathrm{Cl}$. tetani on half-antitoxic serum (tetanus) fresh blood agar. The fine spreading growth is inhibited by tetanus antitoxic serum on the left-hand half of the plate. Natural size. 
Cultural reactions of Cl. tetani

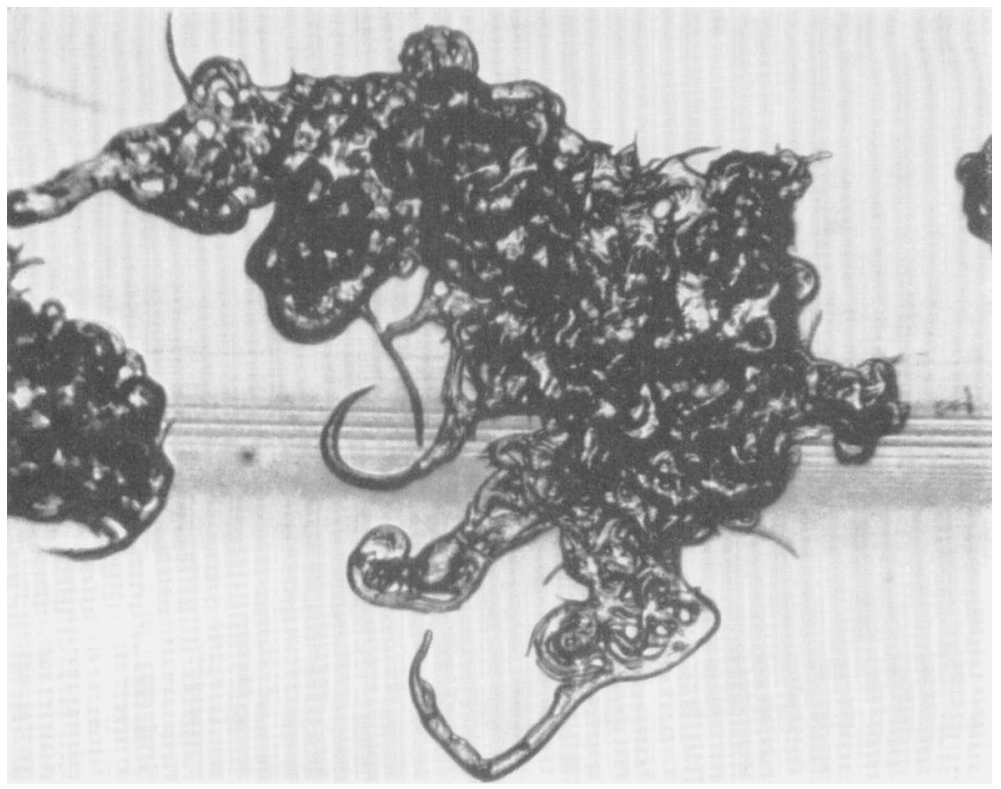

FIG. 8.-Discrete colony of a motile strain of $\mathrm{Cl}$. tetani on fresh blood agar containing tetanus antitoxic serum to a concentration of 40 units tetanus antitoxin per $\mathrm{ml}$. $\times 42 \cdot 5$.

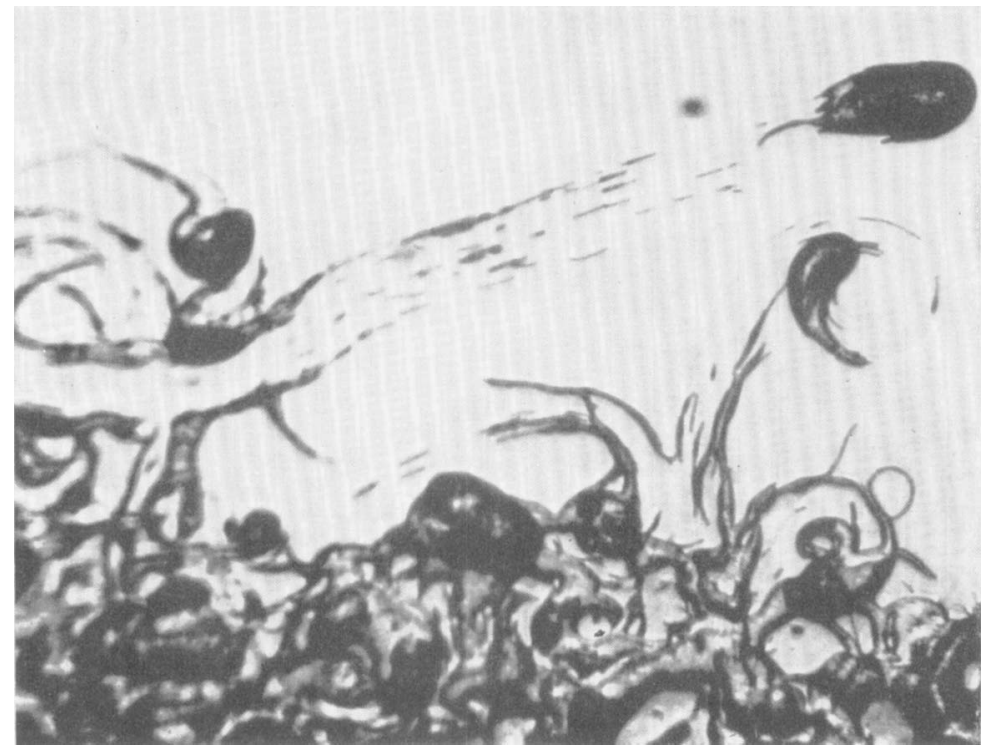

FIG. 9.- Motile daughter colonies of a motile strain of $\mathrm{Cl}$. tetani on fresh. blood agar containing tetanus antitoxic serum to a concentration of 40 units tetanus antitoxin per ml. $\times \mathbf{4 2 \cdot 5}$. 
might allow the development of wider and more photographable zones of opacity.

The most striking feature of these cultures, however, was complete abolition on the antitoxic serum half of the plates of the small rhizoidal outgrowths that are characteristic of surface colonies of these organisms (figs. 5 and 6). Because commercial tetanus antitoxic sera are prepared by the injection of filtrates of autolysates of $\mathrm{Cl}$. tetani into the horse, the most likely explanation for this was that antibody to the vegetative organism, probably somatic antibody, was causing "agglutination" of the growing surface cultures. If this was so, then one would expect the horse tetanus antitoxic serum to have a similar restricting influence on the surface growth of motile strains of the organism.

Accordingly, our motile strains of $\mathrm{Cl}$. tetani were cultured on " halfantitoxin" fresh horse blood agar plates containing 1.5 per cent. of agar. In every case there was complete inhibition of swarming growth on the "antitoxin " half of the plate. When examined under the plate microscope, colonies and areas of confluent growth of $\mathrm{Cl}$. tetani on antitoxin-containing media showed a highly irregular edge, but the finely filamentous outgrowths that are characteristic of spreading cultures were absent. These were replaced by short coarse rhizoids of truncated appearance, which not infrequently gave the impression that they had been turned back upon themselves. In addition, some strains produced small motile daughter colonies, similar in appearance to those described by Turner and Eales (1941) (figs. 7-9).

This principle was applied to the separation of other anaerobes from mixtures with $\mathrm{Cl}$. tetani in plate cultures. Mixtures of either $\mathrm{Cl}$. welchii type A, $\mathrm{Cl}$. bifermentans, $\mathrm{Cl}$. oedematiens type A, Cl . sporogenes, $\mathrm{Cl}$. histolyticum or Cl. septicum with $C$ l. tetani were tested on "half-antitoxin" plates of horse blood agar. In most cases it was a simple matter to pick off discrete colonies of the required organism from the "antitoxin " half of the plate; the untreated half of each plate showed a confluent growth of $\mathrm{Cl}$. tetani overlying colonies of the other species. In other cases, however, there was not complete inhibition of swarming, probably due to uneven application of antibody. Incorporation of tetanus antitoxic serum in the plating medium at a concentration of 40-60 units of antitoxin per $\mathrm{ml}$, however, has been uniformly successful in inhibiting the spreading growth of $\mathrm{Cl}$. tetani, and the method is recommended, especially when $\mathrm{Cl}$. tetani is a troublesome contaminant in mixtures with other exacting clostridia. Although we have not investigated the matter, media containing antitoxic serum may provide a useful alternative to firm agar when viable counts of $\mathrm{Cl}$. tetani are required.

\section{Phosphatase and DNase activities of Cl. tetani}

None of the 71 strains of $\mathrm{Cl}$. tetani showed evidence of phosphatase activity when tested by the method of Bray and King.

In the plate test for DNase activity, 40 of the 71 strains (56 per cent.) gave clear-cut positive results.

J. MED. MICROBIOL.-VOL. 3 (1970) 


\section{Discussion}

Apart from the neurotoxin (tetanospasmin) and the oxygen-labile haemolysin (tetanolysin), little close attention has been paid to the production by $\mathrm{Cl}$. tetani of other enzymic substances. The relevant earlier reports on gelatinase and proteinase activities have been mentioned already. The organism is well known as non-lipolytic and as a non-lecithinase C-producer. Hall (1922) suggested that the late coagulation produced by some strains in whole-milk medium might be due to a rennin-like enzyme. In an investigation of fibrinolysin production by gas gangrene anaerobes, Reed, Orr and Brown (1943) failed to detect fibrinolytic activity amongst any of five toxigenic strains of $\mathrm{Cl}$. tetani, whilst Bray and King (1943) reported that the two strains they tested on their phenolphthalein phosphate medium were phosphatase-negative. Several clostridia are known to produce deoxyribonucleases (Oakley and Warrack, 1951; Warrack, Bidwell and Oakley, 1951), but this enzyme has not been sought in cultures of Cl. tetani.

The method used for testing a growing organism for any particular property clearly may have a significant effect on the result of the test, and therefore on the property assigned to the organism. In general terms it may be said that the most practically useful methods are those that are simple to perform and produce an unequivocal end-point after a reasonably short incubation period. The advantages to be gained by the careful choice of method are well illustrated by our findings in the gelatinase tests, amongst which the gelatin agar plate method of Frazier was superior in every respect to the other methods examined, giving 100 per cent. clear-cut positive results in $48 \mathrm{hr}$.

For detection of bacterial proteinases in cultures in cooked-meat broth and inspissated serum, fairly overt proteolytic activity is required. On the other protein media used, however, and especially on heated serum agar, milk agar and fibrin agar with tryspin inhibitor, in which comparatively low concentrations of substrate are used, even minor degrees of proteinase activity produce rapid and conspicuous changes that rarely need subjective interpretation. Our failure to demonstrate proteinase production by any of the strains of $\mathrm{Cl}$. tetani on any of the media employed leads to the conclusion that the organism is rightly regarded as non-proteolytic.

In contrast to the earlier findings of Reed et al., more than half of our strains were fibrinolytic, an activity that is almost certainly due to a kinase rather than a proteinase, since it is inhibited by soy bean trypsin inhibitor. Because Reed and his colleagues examined only five strains of the organism, it is possible that they studied a random sample of genuinely non-fibrinolytic organisms. On the other hand, their method for the detection of fibrinolysis, in which the indicating effect is dissolution of a fibrin clot (Tillett and Garner, 1933), is less sensitive than the fibrin agar method of Jacobs et al. (1964).

Oakley and Warrack, and Warrack et al., who were concerned with the quantitative determination of deoxyribonuclease activity of $\mathrm{Cl}$. welchii and Cl. septicum, used a number of indicating effects; these included the change in staining properties of fixed films of rabbit leucocytes, viscometric measurements on solutions of sodium deoxyribonucleate, and the "ACRA" test. None of 
these tests is particularly convenient for the all-or-none qualitative determination of deoxyribonuclease activity, although the rabbit leucocyte test was recently employed by Arseculeratne, Panabokké and Wijesundera (1969) as the indicator for DNase activity of $\mathrm{Cl}$. sordellii. Much less troublesome and time-consuming is the DNA agar medium originally described by Jeffries, Holtman and Guse (1957). By this method, more than half of our strains gave clear-cut positive results. There was no apparent relation between the abilities of strains to produce tetanospasmin, DNase and fibrinolysin.

The earlier suggestion put forward by Hall that the coagulation of milk by some strains of $\mathrm{Cl}$. tetani is due to a rennin-like enzyme has been confirmed. This part of the present investigation developed following the incidental observation that all of our strains of $\mathrm{Cl}$. tetani produce zones of diffuse opacity in cultures on firm milk agar. Unless the strains are non-motile, the reaction cannot be observed on 1.5 per cent. agar because of confluent growth. This rennin-like activity of $\mathrm{Cl}$. tetani, which was shown to be present in culturesupernatants, to be active under both aerobic and anaerobic conditions, and to be inhibited by tetanus antitoxic sera, was also easily detectable in 10 per cent. milk broth cultures, but much less conveniently and certainly in whole-milk cultures. Reactions indistinguishable from those of $\mathrm{Cl}$. tetani are produced in both milk broth and milk agar by $\mathrm{Cl}$. oedematiens types $\mathrm{A}$ and $\mathrm{B}$, and are probably also due to a rennin-like enzyme. Similar reactions produced by lactose-fermenting organisms, and especially $\mathrm{Cl}$. welchii, are due to acid, rather than to enzymatic, precipitation. This is easily demonstrated by adding a little indicator (phenol red) to a culture in milk broth after incubation to show the production of acid, or by neutralising the culture, when the precipitate redissolves.

Although whole-milk medium is widely used for the identification and classification of clostridia, its chief interest today is a historical one. All the information that can be obtained (often with difficulty and uncertainty) from cultures of clostridia in whole milk is more easily, more quickly and much more certainly obtained by other methods. Whole-milk cultures should be abandoned; definitive information about proteolysis, enzyme clotting and lactose fermentation is obtained by the use of 10 per cent. milk agar or milk broth, and a conventional lactose fermentation test.

The inhibitory effect of commercial horse tetanus antitoxic sera on the swarming growth of $\mathrm{Cl}$. tetani is doubtless due to the presence of antibody to the vegetative cell. Although we have not followed the matter up experimentally, it seems probable that somatic antibody is the factor involved, since strains of Cl. tetani are known to possess a common O-antigen, but may have typespecific $\mathrm{H}$-antigens. In any event, tetanus antitoxic sera incorporated into solid media at a concentration of 40-60 units of antitoxin per $\mathrm{ml}$ had no adverse effect on the growth of other clostridia tested, but prevented the swarming of Cl. tetani and allowed the development of discrete colonies. By this means we have been able to isolate other clostridia from mixtures with $\mathrm{Cl}$. tetani without difficulty, both by selection of discrete colonies, and by allowing spreading species such as $\mathrm{Cl}$. septicum to swarm from the restricted growth of $\mathrm{Cl}$. tetani. 


\section{SUMMARY}

Probably because $C l$. tetani is a well-defined species whose recognition is rarely difficult, no recent attempts have been made to clarify the present uncertainties about its gelatinolytic and proteolytic activity. In the present study of 71 strains of the organism, all of them were shown to produce gelatinase, and none was proteolytic.

A proportion of the strains (49 of 71) produced a fibrinolytic enzyme, which behaved like a kinase.

A proportion of the strains (40 of 71) produced a deoxyribonuclease.

None of the strains produced phosphatase.

All 71 strains produced an intense diffuse opacity on milk agar, and complete precipitation of casein in milk broth due to the production of a rennin-like enzyme. This enzyme was present in culture-supernatants, was active under both aerobic and anaerobic conditions, and was specifically inhibited by tetanus antitoxic sera. With the exception of $\mathrm{Cl}$. oedematiens types $\mathrm{A}$ and $\mathrm{B}$, the reactions of all other clostridia tested on milk agar and in milk broth were dissimilar to those of $\mathrm{Cl}$. tetani.

Commercial horse tetanus antitoxic serum inhibits the swarming growth of $\mathrm{Cl}$. tetani in plate cultures. Advantage may be taken of this in the separation of other anaerobic organisms from mixtures with $\mathrm{Cl}$. tetani.

We gratefully acknowledge the patient and skilful assistance of Mr J. Harrison who took the photographs. We are indebted to Drs S. P. Lapage, J. H. Payne and W. J. Ryan of the Public Health Laboratory Service for providing many of the strains of $\mathrm{Cl}$. tetani.

\section{REFERENCES}

AdAmson, R. S. . . . . . . . . . 1919-20. J. Path. Bact., 23, 241.

Adamson, R. S., AND Cutler, D. W. . 1917. Lancet, 1, 688.

Arseculeratne, S. N., Panabokké, 1969. J. Med. Microbiol., $2,37$.

R. G., AND WIJESUNDERA, S.

BRAY, J., AND KING, E. J. . . . . . . 1943.

Breed, R. S., Murray, E. G. D., AND 1957. SMITH, N. R. . . . . . . .

Collins, C. H. . ～～～～～～～～～～～～ 1967.

CRUickshank, R. . . . . . . 1965.

Fildes, P.

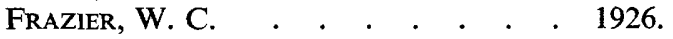

HaLl, I. C. . . . . . . . . . . . 1922.

JACOBS, S. I., WILlis, A. T., AND GoOD- 1964. BURN, GILLIAN M.

JefFries, C. D., Holtman, D. F., AND 1957. Guse, D. G.

Kendall, A. I., Day, A. A., AND 1922. WALKER, A. W.

Lack, C. H., and Wailling, D. G. . . 1954.

MOORE, W. B. . . . . . . . . 1968.

OAKLey, C. L., and Warrack, G. 1951.

J. Path. Bact., 55, 315.

Bergey's Manual of determinative bacteriology, 7th ed., London.

Microbiological methods, 2nd ed., London.

Medical microbiology, 11th ed., Edinburgh.

Br.J. Exp. Path., 6, 62.

J. Infect. Dis., 39, 302.

Ibid., 30, 445.

J. Path. Bact., 87, 151.

J. Bact., 73, 590.

J. Infect. Dis., 30, 141.

J. Path. Bact., 68, 431.

J. Gen. Microbiol., 53, 415.

HARRIET

J. Path. Bact., 63, 45. 
Reddish, G. F., AND Rettger, L. F. . 1924. J. Bact., 9, 13.

REED, G. B. . . . . . . . . . 1948. In Bacterial and mycotic infections of man, ed. by R. J. Dubos, Philadelphia, p. 355.

ReEd, G. B., AND ORR, J. H. . . . . 1941. War Med., Chicago, 1, 493.

REED, G. B., ORR, J. H., AND Brown, 1943. J. Bact., 46, 475. HELEN J.

ROBERTSON, MURIEL . . . . . . 1917. Lancet, 1, 780.

SMITH, L. DS. . . . . . . . 1955. Introduction to the pathogenic anaerobes, Chicago.

Smith, L. DS., AND Holdeman, Lillian 1968. The pathogenic anaerobic bacteria, V. Chicago.

SPRAY, R. S. . . . . . . . . . . . . 1936.

TILLETT, W. S., AND GARNER, R. L. . . 1933.

J. Bact., 32, 135.

Turner, A. W., and Eales, Catherine E. 1941.

J. Exp. Med., 58, 485.

Austral. J. Exp. Biol. Med. Sci., 19, 167.

Walbum, L. E., and Reymann, G. C. - 1934. J. Path. Bact., 39, 669.

WARRACK, G. Harriet, BidWell, Ethel, 1951. Ibid., 63, 293. AND OAKLeY, C. L.

WILlis, A. T.

1964. Anaerobic bacteriology in clinical medicine, 2nd ed., London.

Willis, A. T., AND HobBs, G. . . 1959. J. Path. Bact., 77, 511.

Wilson, G. S., AND Miles, A. A. - . 1964. Topley and Wilson's Principles of bacteriology and immunity, 5th ed., London. 